\title{
EVALUATION OF SOME JAPANESE'S GARDEN PLANT SPECIES FOR ITS TOLERANCE TO AIR POLLUTION A. COMPARISON OF DIFFERENT SPECIES GROWN IN A SPECIFIC PART OF THE GARDEN
}

\author{
FAWZIA GH. ZENNA ${ }^{1}$, LOBNA S. TAHA ${ }^{2}$ and SAYED M. SHAHIN ${ }^{1}$ \\ 1. Botanical Gardens. Res. Dept., Hort. Res. Inst., ARC, Giza, Egypt. \\ 2. Ornamental Plants and Woody Trees Dept., NRC, Dokki, Egypt.
}

(Manuscript received 12 June 2019)

\begin{abstract}
$\mathrm{B}$ ecause the different plant species showed a different behaviour against air pollution in the different sites and even in the same site, the present study was conducted on some selected ornamental plants grown together in different parts of Japanese garden, industrial Helwan City, the greatest Cairo, Egypt during the summer season 2017 to determine the relative tolerance of these plants to air pollution prevailing in this city using the air pollution tolerance index (APTI), which estimated by the use of four physio-biochemical parameters of the leaves, i.e. ascorbic acid content, relative water content (RWC \%), leaf extract pH and total chlorophyll content as a practical tool for determining tolerance level of the plants and comparing among themselves. Mature leaf samples were monthly collected for 3 times during the morning hours from the selected ornamental plants grown in the North, Middle, South, East and West parts of the garden for analyzing. The APTI scale was used for determination of sensitivity/tolerance degree for every plant species. The obtained results indicated that a considerable variation in the means of ascorbic acid content, RWC \%, pH of the leaf extract, total chlorophyll content and APTI values were observed among the different plant species selected from each part. Thus, every species exhibited a sole behaviour than the other ones under air pollution conditions of the same place. Based on the APTI values of various species in every individual place of the garden and the corresponding tolerance degree, it can be advised to plant Yucca elephantipes, Ficus benjamina, Bauhinia variegata and Lantana camara species in the North part; Yucca elephantipes, Cassia nodosa, C. fistula and F. benjamina species in the Middle part; $C$. fistula, Delonix regia (Poinciana), Ficus cycomorus (Gemez), Lantana camara and Washingtonia filifera palm in the South part; Ficus benghalensis, Codiaeum variegata (Croton), Duranta erecta and Lantana camara species in the East part, while for the West part, it is prefer to plant Delonix regia (Pionciana), Pinus halepensis, Bauhinia variegata, Ficus retusa ( $F$. nitida), F. microcarpa "Hawii", Lantana camara and Brachychiton porpulenum species as the most suitable ornamental plants for air pollution load prevailing in every part of Japanese garden.
\end{abstract}

Key words: Air pollution, air pollution tolerance index (APTI), ornamental plants.

\section{INTRODUCTION}

It is well known that various plant species exhibited a different behaviour for the different air pollutants, and any plant part could be without bias used as biomonitors, especially the leaves, which are usually the most glore and most obvious 
vital receptors for large number of air pollutants (Jyothi and Jaya, 2010). The response of plants towards atmosphere was evaluated by air pollution tolerance index (APTI), which was successfully used by several authors as an important tool for measuring tolerance and sensitivity of plant species to air pollution. In this regard, Tripathi et al., (2009) concluded that Pongamia pinnata (15.8), Pithecolobium dulcis (34.8), Holoptelea integrifolia (55.8) and Saraca indica (52.0) had very high APTI values over control, so they are the highest tolerant tree species, Ficus rumphii (35.7), Azadirachta indica (30.5) and Grevillea robusta (34.3) have slightly more APTI values over control, so they ranked as moderately tolerant tree species. On the other hand, Alstonia scholaris (21.5), Cassia simea (6.09) and Bauhinia variegata (18.22) have less APTI values than control, so they are considered sensitive species. Further, Begum and Harikrishna, (2010) mentioned that the most tolerant tree species with respect to APTI and heavy metal concentration were Ficus religiosa, Azadirachta indica and Pongamia pinnata, whereas the APTI for Acacia melanoxylon, Caesalpinia pulcherrima, Ficus benghalensis, F. religiosa, Delonix regia, Morinda pubescens and Saraca indica species are reported lower and are considered as sensitive species.

Similar observations were also revealed by Dwivedi and Tripathi (2007) on Ricinus communis and Lepidium sativum, Dwivedi et al., (2008) on Ficus religiosa, Jyothi and Jaya (2010) on Polyalthia longifolia, Alstonia scholaris, Mangifera indica and Clerodendron sp., Chandawat et al., (2011) on Ficus benghalensis, F. religiosa, F. glomerata, Azadirachta indica and Polyalthia longifolia, Krishnaveni et al., (2013) on Nerium oleander, Ficus benghalensis, Psidium guajava, Spathodea campanulata and Opuntia ficus-indica, Babu et al., (2013) on Aegle marmelos, Bougainvillea spectabilis, Cassia auriculata and Ziziphus zizyphus, Bora and Joshi (2014) on Azadirachta indica, Eucalyptus sp., Ficus religiosa, Saraca indica and Tictona grandis, Noor et al., (2015) on 15 common flora plant species of India, Akilan and Nandhakumar (2016) on Nerium oleander, Tamarindus indica, Azadirachta indica and Pungamia pinnata, as well as Kaur and Nagpal (2017) who reported that highest APTI (82.14) was recorded by Nerium oleander plants growing along the roadsides during the pre-monsoon season, while the least APTI (18.59) was attained by Tabernaemontana coronaria in the post-monsoon season. According to the APTI value, the four roadside shrub species of Fam. Apocynaceae could be arrangement in the following descending order: Alstonia scholaris $>N$. oleander $>$ T. coronaria $>$ Thevetia peruviana.

On Ficus religiosa, Delonix regia, Polyalthia longifolia, Plumeria sp. and Azadirachta indica grown on highly polluted roadside, Kumari and Deswal (2017) found that all the previous species are sensitive to air pollution. Moreover, Salaa and Al-Kawaz (2017) noticed that Conocarpus lancifolius can be more tolerant towards air pollution that produce from brick factory than Dodonaea viscosa. Recently, Patel and Kumar (2018) cited that based on APTI and API values, Ficus benghalensis and F. 
religiosa are the most tree species appropriate for green belt development in industrial area.

However, the purpose of this study is evaluating the ability of some tree and shrub species grown in specific part of the Japanese garden in Egypt to tolerate air pollution of Helwan industrial area using air pollution tolerance index (APTI), as a practical method for determining plant species tolerance towards air contamination.

\section{MATERIALS AND METHODS}

The present study was carried out at the laboratories of both Hort. Res. Inst., ARC and Agric. and Biol. Res. Div., NRC, Giza, Egypt during summer season, 2017 in order to compare tolerance of some tree and shrub species grown in specific parts of Japanese Garden at Helwan district as a major industrial city includes iron, steel, textiles, cement, fertilizers, ceramics and asbestos industries, which result in dusts, heavy metals, particulate matter, ammonia $\left(\mathrm{NH}_{3}\right)$, formaldehyde $(\mathrm{HCOH})$, fluorides $(\mathrm{F})$ and fibrous silicate minerals. The previous sources also emit great amounts of gases, such as $\mathrm{SO}_{2}, \mathrm{H}_{2} \mathrm{~S}, \mathrm{CO}$ and $\mathrm{NO}_{2}$ due to inadequate combustion of feul high in sulphur content (Andrew, 2005).

The Japanese garden locates the North-East Helwan city, covering area of $40468 \mathrm{~m}^{2}$ (9.64 fed.) and bounded from the North by Sherif st., from South by Mohamed Sayed Ahmed st., from East by Fayzi Basha st. and from West by Dr. Mostafa Safwat st., where the main entrance of the garden is present. To perform such trial, the garden is divided to 12 beds, as every bed has various types of plant species (Photo, 1 ).

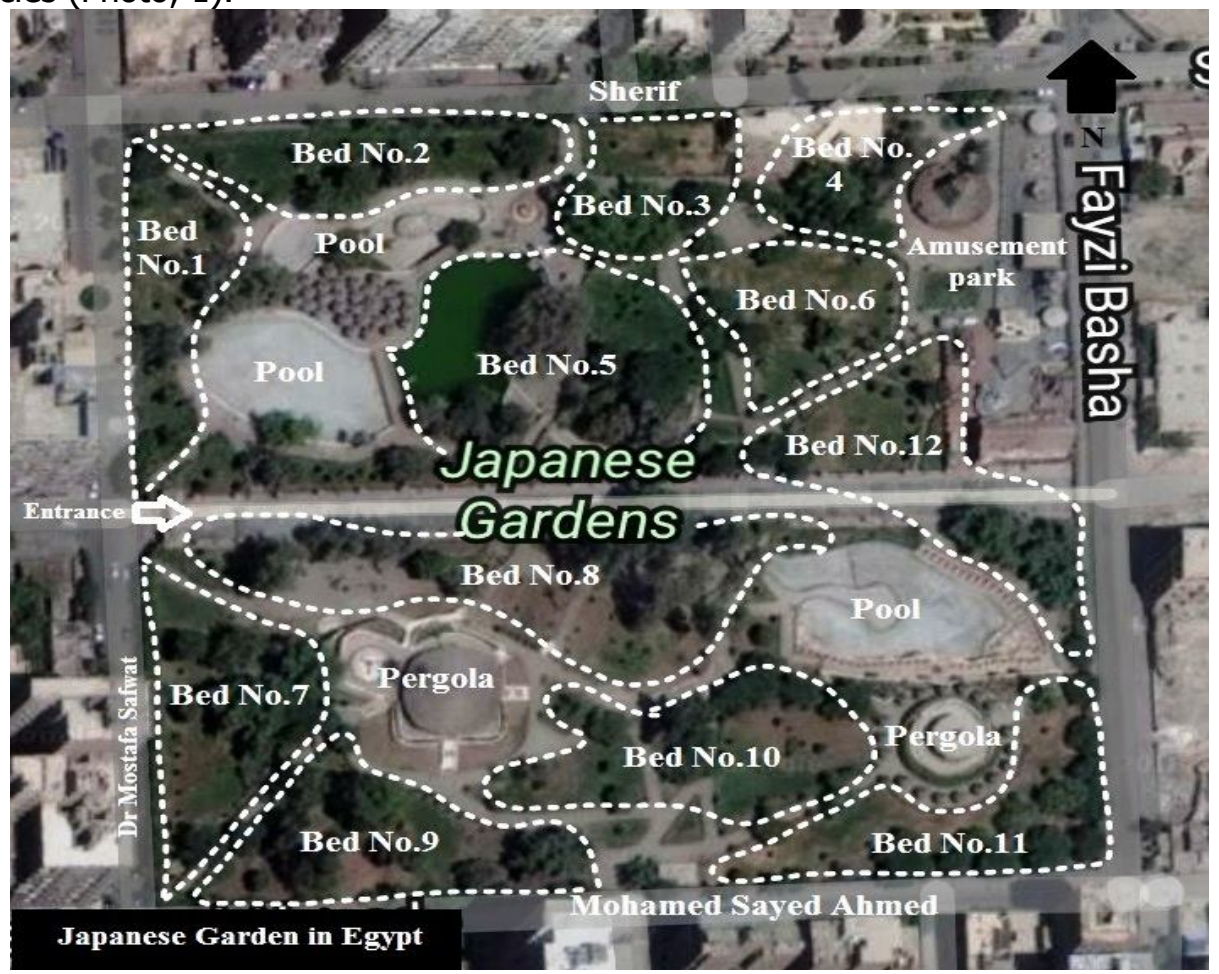

Photo 1. The Japanese garden after division into 12 beds. 


\section{Plant species under study:}

The botanical and common names of trees and shrubs species selected for this study are given in the following table as mentioned in Bailey (1976).

\begin{tabular}{|c|c|c|c|c|}
\hline No & Botanical name & Common name & Family & Native \\
\hline 1 & Acalypha marginata Mull. Arg. & Copper-leaf & Euphorbiaceae & Pasific Island \\
\hline 2 & $\begin{array}{l}\text { Araucaria heterophylla (Salisb) } \\
\text { Franco. }\end{array}$ & Norfolk Island pine & Araucariaceae & Norfolk Island \\
\hline 3 & Bauhinia variegata $\mathrm{L}$. & $\begin{array}{l}\text { Orchid tree, or khof-el- } \\
\text { Gamal }\end{array}$ & Leguminosae & India, China \\
\hline 4 & Bougainvillea glabra Choisy. & Paper-flower & Nyctaginaceae & Brazil \\
\hline 5 & Brachychiton populneum R.Br. & Bottle tree & Sterculiaceae & Queens land \\
\hline 6 & $\begin{array}{l}\text { Breynia disticha J. R. Forst \& G. } \\
\text { Forst. }\end{array}$ & Snowbush & Euphorbiaceae & Pasific Island \\
\hline 7 & Cassia fistula $\mathrm{L}$. & Golden shower & Leguminosae & India \\
\hline 8 & Cassia nodosa Buch. Ham. ex Roxb. & Pink and White shower & Leguminosae & Eastern Himalaya \\
\hline 9 & $\begin{array}{l}\text { Clerodendron inerme (Volkameria } \\
\text { inerme L.) }\end{array}$ & Glory bower & Lamiaceae & Australia, Asia, Malesia \\
\hline 10 & Codiaeum variegatum (L.) A. Juss. & $\begin{array}{l}\text { Variegated laurel, } \\
\text { Croton. }\end{array}$ & Euphorbiaceae & $\begin{array}{c}\text { Malaya, Sirlanka, } \\
\text { Pasific Islands, Java } \\
\text { Africa }\end{array}$ \\
\hline 11 & Cycas revoluta Thunb. & Sago palm & Cycadaceae & Japan \\
\hline 12 & Delonix regia Raf. & Poinciana, Flame tree & Leguminosae & Madagascar \\
\hline 13 & Dendrocalamus giganteus Nees. & Giant Bamboo & Gramineae & India \\
\hline 14 & Dodonaea viscosa (L.) Jacq. & Hap bush & Sapindaceae & Tropic and subtropics. \\
\hline 15 & Duranta repens L. & $\begin{array}{c}\text { Brazilian Sky } \\
\text { Flower (duranta) }\end{array}$ & Verbenaceae & $\begin{array}{c}\text { Caribbean and South } \\
\text { America }\end{array}$ \\
\hline 16 & Duranta repens "Variegata" & Flower (duranta) & Verbenaceae & $\begin{array}{l}\text { Caribbean and South } \\
\text { America }\end{array}$ \\
\hline 17 & Eucalyptus camaldulensis Dhnh. & Red gum & Myrtaceae & $\begin{array}{c}\text { Australia, New Guinea, } \\
\text { Philippine, Tasmania, } \\
\text { Timor and Java } \\
\end{array}$ \\
\hline 18 & Ficus benghalensis L. & \begin{tabular}{|c|} 
Banyan tree \\
\end{tabular} & Moraceae & India-Pakistan \\
\hline 19 & Ficus benjamina L. & $\begin{array}{c}\text { Benjamin tree, Weeping } \\
\text { ficus }\end{array}$ & Moraceae & India, Malay, Australia \\
\hline 20 & Ficus elastica "Decora" (Jack) Hort. & \begin{tabular}{|l|} 
Mistltoe ficus \\
\end{tabular} & Moraceae & Malay \\
\hline 21 & Ficus elastica Roxb. ex. Hornem. & Rubber tree & Moraceae & India, Nepal \\
\hline 22 & Ficus lyrata Warb & Fiddle-leaf fig & Moraceae & Tropical Africa \\
\hline 23 & Ficus microcarpa nitida "Hawaii" L. & Hawai fig & Moraceae & Tropical Asia \\
\hline 24 & Ficus retusa L. ( F. nidida L.) & Indian laurel & Moraceae & India \\
\hline 25 & Ficus sycomorus L. & Sycamore & Moraceae & $\begin{array}{l}\text { S. Africa to Egypt and } \\
\text { Lebanon }\end{array}$ \\
\hline 26 & Grevillea robusta A. Cunn. & Silky oak & Proteaceae & Queens land \\
\hline 27 & Hibiscus rosa-sinensis L. & Rose of China & Malvaceae & China \\
\hline 28 & Kigelia pinnata Oliv. & Sausage tree, Mashtura & Bignoniaceae & Tropical Africa \\
\hline 29 & Lantana camara L. & Yellow sage & Verbenaceae & Tropical America \\
\hline 30 & Nerium oleander $\mathrm{L}$. & Oleander & Apocynaceae & $\begin{array}{c}\text { Mediterranean region } \\
\text { to Japan }\end{array}$ \\
\hline 31 & $\begin{array}{l}\text { Pinus canariensis Sweet ex. K. } \\
\text { Spreng }\end{array}$ & Canary Is. pine & Pinaceae & Canary Island \\
\hline 32 & Pinus halepensis Mill & Aleppo pine & Pinaceae & Mediterranean region \\
\hline 33 & Pittosporum tobira Thunb. (Ait.) & $\begin{array}{c}\text { Japanese P., Australian } \\
\text { laurel }\end{array}$ & Pittosporaceae & China, Japan \\
\hline 34 & Plumeria alba L. & Temple tree, Frangibani & Apocynaceae & \begin{tabular}{|l|} 
PuertoRico \\
\end{tabular} \\
\hline 35 & Punica granatum L. & Pomegranat & Punicaceae & $\begin{array}{l}\text { South East Europe and } \\
\text { South Asia }\end{array}$ \\
\hline 36 & Schinus molle L. & California pepper tree & Anacardiaceae & Peru \\
\hline 37 & Schinus terebenthifolius, Roddi & Brazilian pepper tree & Anacardiaceae & Brazil \\
\hline 38 & Strelitzia reginae Ait. & Bird-of-paradise & Strelitziaceae & South Africa \\
\hline 39 & Tamarix articulata Vahl. & Athel & Tamaricaceae & N.E. Africa and W. Asia \\
\hline 40 & Thuja orientalis (L.) Franco. & Oriental arborvitae & Cupressaceae & China, Korea \\
\hline 41 & Tipuana speciosa Benth. & Tipu tree & Leguminosae & S. America \\
\hline 42 & Washingtonia filifera H. Wendl. & Desert fan palm & Palmae & California \\
\hline 43 & Yucca elephantipes Regel & Spineless Y. Arborescent & Agavaceae & Guatemala \\
\hline 44 & Ziziphus spina-christi L. & Sidder & Rhamnaceae & $\begin{array}{l}\text { Tropical and N,E. } \\
\text { Africa }\end{array}$ \\
\hline
\end{tabular}




\section{Collection of leaf samples:}

Leaf samples were monthly collected for 3 times in the summer during the period from $15^{\text {th }}$ June to $15^{\text {th }}$ August 2017 , as the fully mature leaves were picked in the triplicates in the morning hours from the selected plant species grown in the north part of the garden (represented by beds No. 2, 3 and 4), middle part (represented by beds No. 5, 6 and 8), south part (represented by beds No. 9, 10 and 11,) east part (represented by bed No. 12) and west part (represented by beds No. 1 and 7).

\section{Determination of the four physio-biochemical parameters:}

In order to estimate the air pollution tolerant index as an index denotes the ability of plant to withstand any pollution, the leaf samples were analyzed for relative water content (RWC\%), pH of leaf extract, total chlorophylls and ascorbic acid contents using the methods of Prasad and Rao (1982), Moran (1982) and Sadasivam and Manickam (1996), respectively.

\section{Air pollution tolerance index (APTI) calculation:}

Finally, the four physio-biochemical parameters mentioned above were used for computing the APTI for the selected trees and shrubs using the equation proposed by Singh and Rao (1983): APTI $=[$ AsA $($ T. Chlo. + pH $)+$ RWC $] \div 10$.

Where: $\mathrm{AsA}=$ ascorbic acid content $(\mathrm{mg} / 100 \mathrm{~g}$ f.w.), T. Chlo = total chlorophyll content (mg/g f.w.), $\mathrm{pH}$ of the leaf extract and RWC: relative water content (\%).

According to APTI values, plant species can be categorized into sensitive, moderately tolerant (Intermediate) and tolerant, where APTI values were ranged from 1 to 100 by Begum and Harikrishna (2010), and sensitivity/tolerance degree of plants can be determined from the following APTI scale:

\begin{tabular}{|l|l|}
\hline APTI value & Response degree \\
\hline$<1$ & Very sensitive \\
\hline $1-16$ & Sensitive \\
\hline $17-29$ & Intermediate/moderately tolerant \\
\hline $30-100$ & Tolerant \\
\hline
\end{tabular}

Data were then tabulated and statistically analyzed using the program of SAS Institute (2009), followed by Duncan's New Multiple Range Test (Steel and Torrie, 1980) for means comparison.

\section{RESULTS AND DISCUSSION}

\section{Comparing physio-biochemical characters among the different tree and shrub} species grown in:

\section{1- The North part of the garden:}

It is obvious from data averaged in Table (1) that ascorbic acid content (mg/100 g f.w.) was greatly high in the highly tolerant Yucca elephantipes plants cultivated in bed No.3, $(427.6 \mathrm{mg} / 100 \mathrm{~g}$ f.w.) with highly significant differences 
compared to the other plant species grown in the North part. The content of such constituent, however, reduced in the intermediate plants to a range of 14.3-28.1 and in the sensitive ones to a range of 13.1-15.5 (mg/100 g f.w.).

The high concentration of ascorbic acid in Yucca elephantipes that tolerated air pollution of Helwan City may indicate the role of ascorbic acid in preventing the harmful effects of air pollutants on plant tissues. In this regard, Kaur and Nagbal (2017) stated that ascorbic acid is the active antioxidant which keeps cell division and cell membrane stability in plants during pollution stress by removing cytotoxic free radicales and reactive oxygen species (ROS) produced by photo-oxidation of pollutants. Moreover, Jyothi and Jaya (2010) suggested that ascorbic acid play a vital role in cell wall synthesis, defense and cell division. Higher ascorbic acid in leaf tissues of the plant is a sign of its tolerance to air pollution, while lower content in the leaves of other plants supports their sensitivity towards air pollutants.

The previous results are well supported by many other findings detected by Dwivedi and Tripathi (2007) on Ricinus communis (as most resistant wild plant) and Lepidium sativum (as sensitive plant), Tripathi et al., (2009) on Pongamia pinnata, Saraca indica, Azadirachta indica, Ficus remphii, Grevillea robusta, Cassia simea and Bauhinia variegata, Chandawat et al., (2011) on Ficus benghalensis, F. religiosa, F. glomerata, Azadirachta indica and Polyalthia longifolia, Noor et al., (2015) on Amaranthus viridis, Cannabis sativa, Chenopodium album, Lantana camara, Melia azadirachta, Eucalyptus globules, Ricinus communis, Withania somnifera and Ziziphus nummulari and Akilan and Nandhakumar (2016) who declared that Nerium oleander was more tolerance in industrial and transportation areas than Azadirachta indica, Pungamia pinnata and Tamarindus indica. Recently, Patel and Kumar (2018) cited that higher ascorbic acid contents ( $\mathrm{mg} / 100 \mathrm{~g} \mathrm{f.w}$ ) were recorded by the high tolerant plant species, included: Michelia champaca (7.31), F. religiosa (6.98), Azadirachta indica (6.79), Polyalthia longifolia (6.42), Cassia siamea (6.19) and C. fistula (6.09). Ascorbic acid is concentrated mostly in chloroplasts that act as an antioxidant enhances resistance to adverse environmental conditions, including air pollution.

On the other hand, moderately tolerant species possessed higher relative water content (\%) than tolerant and sensitive species, with few exceptions. However, the high RWC was observed in the leaves of Schinus terebenthifolius tree grown in bed No.3 (97.16\%), followed by Lantana camara shrub (96.17\% for plants cultivated in bed No.2 and $95.14 \%$ for those cultivated in bed No.3) and Delonix regia grown in bed No.2 (95.74\%) with non-significant differences among themselves, while the least RWC recorded by Nerium oleander shrub $(60.00 \%$ in bed No.3), followed by Tamarix articulata tree (63.69 \% in bed No.4) and Thuja orientalis shrub $(66.09 \%$ in bed No.2) as shown in Table (1). 
Water plays a great role in maintaining the physiological balance of plants under air pollution stress, as the high RWC in plants is useful for drought resistance and acidity dilution inside the leaf cell sap (Babu et al., 2013). Relative water content is directly affect with the protoplasmic permeability in cells causes loss of water and dissolved nutrients, resulting in early senescence of leaves. So, the plants with high RWC under pollution may be tolerant to contaminants (Jyothi and Jaya 2010; Krishnaveni et al., 2013). The results of RWC in the present study are in accordance with those of Begum and Harikrishna (2010) on Ficus religiosa, Azadirachta indica and Pongamia pinnata, Jyothi and Jaya (2010) on Polyalthia longifolia and Clerodendron infortunatum, Krishnaveni et al., (2013) on Ficus benghalensis, Nerium oleander, Opuntia ficus-indica and Psidium guajava, Babu et al., (2013) on Aegle marmelos, Bougainvillea spectabilis, Cassia auriculata and Ziziphus zizyphus and Bora and Joshi (2014) who found that Eucalyptus spp. and Tectona grandis recorded $75 \%$ RWC, whereas Saraca indica and Shorea robusta recorded $68 \%$ in air polluted area. In this concern, Kaur and Nagpal (2017) revealed that within-site, RWC depicted statistically significant variation among Nerium oleander and Tabernaemontana coronaria, whereas no significant variation was observed among Alstonia scholaris and Thevetia peruviana. Likewise, Kumari and Deswal (2017) noticed that the RWC of Plumeria sp., Delonix regia, Ficus religiosa and Azadirachta indica (as tolerant species) were 91, 90, 83 and $79 \%$, respectively compared to $49 \%$ for the sensitive Polyalthia longifolia, although all of them are the common trees of the highly polluted roadside of Noida, Uttar, Pradesh, India. Recently, Patel and Kumar (2018) decided that Ficus religiosa grown in polluted industrial area has the maximum RWC of $64 \%$, followed by Polyalthia longifolia $60 \%$, Spathodea campanulata $55 \%$ and Ficus benghalensis $55 \%$. Under air pollution, transpiration rates are uaually high, consequently leads to dryness. Thus, the maintenance of RWC by the plant may assess its relative tolerance to pollution. Hence, the high RWCs of plants in the industrial area may be responsible for the normal function of active processes (Dwivedi and Tripathi, 2007).

As for $\mathrm{pH}$ values, data in Table (1) clear that $\mathrm{pH}$ means of plant species grown in the North part of the garden were below 7 with non significant differences in between, except for Delonix regia, Ficus retusa, Lantana camara, F. elastica and Tamarix articurala plant species which significantly rose $\mathrm{pH}$ values to $8.81,7.70,7.51$, 7.50 and 7.16, respectively. However, the least pH records were scored by Schinus terebenthifolius (4.90), followed by Yucca elephantipes (5.20), Thuja orientalis (5.55) and Bauhinia variegata (5.90) exhibiting high acidity of the leaf extract.

The leaf extract $\mathrm{pH}$ level plays a critical role in regulation of pollution sensitivity in plants. The acidic nature of $\mathrm{pH}$ may be ascribed to the diffusion of gaseous air pollutants, such as $\mathrm{NO}_{2}, \mathrm{CO}_{2}$ and $\mathrm{SO}$ in the cell sap and conversion them to acid radicales (Noor et al., 2015). Low pH reduces the conversion of hexose sugar 
to ascorbic acid (Jyothi and Jaya, 2010), while high pH favours more activity of ascorbic acid and hence can increase the air pollution tolerance level in plants (Bora and Joshi, 2014). The changes in $\mathrm{pH}$ of leaf extract may influence the stomata sensitivity under of air pollution. Thus, sensitive plants had higher $\mathrm{pH}$ than tolerant ones. Low leaf pH reduces photosynthetic process in plants (Yan and Hui, 2008).

The trend of $\mathrm{pH}$ in this study is coincidence with those explored by Dwivedi et al., (2008) on Ficus religiosa, Babu et al., (2013) on Aegle marmelos, Bougainvillea spectabilis, Cassia auriculata and Ziziphus zizyphus and Kaur and Nagpal (2017) who reported that $\mathrm{pH}$ of leaf samples of different shrub species collected from different sites ranged from 5.46 to 6.48 and from 5.20 to 5.59 for Alstonia scholaris, 5.61-6.36 and 5.53-5.89 for Nerium oleander, 5.84-6.44 and 5.53-5.96 for Tabernaemontana coronaria and 5.56-6.29 and 4.49-5.81 for Thevetia peruviana during the pre- and post-monsoon seasons. In addition, Patel and Kumar (2018) pointed out that leaf pH acidity of Michelia champaca, Cassia fistula, C. siamea and Cascabela thevetia species increased in the polluted area compared with that of control. It has been reported that the lower leaf $\mathrm{pH}$ is due to presence of acidic pollutants.

As shown in Table (1), there were no significant variations in total chlorophyll content (mg/g f.w.) among most tree and shrub species cultivated in the North part of Japanese garden, as the means of such component were closely near together in most cases, but the highest content was observed in the leaves of Bauhinia veriegata in bed No.2 (0.394 mg/g f.w.) and followed by Delonix regia grown in bed No.3 $(0.380 \mathrm{mg} / \mathrm{g}$ f.w. $)$. On the contrary, the lowest content was achieved by the leaves of Lantana camara in bed No.3 $(0.099 \mathrm{mg} / \mathrm{g}$ f.w. $)$, which followed by Tamarix articulata and Yucca elephantipes that gave 0.166 and $0.185 \mathrm{mg} / \mathrm{g}$ f.w., respectively.

Evaluation of chlorophyll content is one of the important ways to assess the effects of air pollution on plants, as it plays the major role in providing greening to the plants and helping in sunlight catchment and its conversion to chemical energy necessary for photosynthesis process (Dwivedi and Tripathi, 2007). High pollution load, high moisture content and blocking on the stomatal pores on the leaf surface because of dust accumulation might be the main reasons for the low chlorophyll concentration in leaf samples obtained from plants grown in polluted sites (Noor et al., 2015). Air pollutants may cause a degradation of chlorophyll molecule to pheophytin by substituting $\mathrm{Mg}^{++}$ions with two hydrogen atoms (Rahmawati et al., 2014). Air pollution decreases the efficiency of chloroplasts, leading to reducing of photosynthetic rate and stomatal conductance, premature leaf fall, and hence low productivity (Bora and Joshi, 2014). Chlorophyll concentration usually varies from species to another, leaf age, pollution level, as well as biotic and abiotic conditions prevailing in the polluted area (Noor et al., 2015). Similar observations to the above ones were also documented for Bauhinia variegata and Cassia siamea by Tripathi et al., (2009), Alstonia scholaris, 
Clerodendron infortunatum, Polyalthia longifolia, Mangifera indica and Eupatorium odoratum by Jyothi and Jaya (2010), Conocarpus lancifolius and Dodonaea viscosa by Salaa and Al-Kawaz (2017), and for Azadirachta indica, Cassia fistula, C. siamea, Ficus religiosa and Polyalthia longifolia by Patel and Kumar (2018).

Air pollution tolerance index (APTI), as a real indicator for air pollution tolerance was used in the current work to categorize tree and shrub species grown in Japanese garden under air pollution of industrial Helwan City to various degree of tolerance according to APTI-scale prepared before by Begum and Harikrishna (2010).

Data averaged in Table (1) revealed that a marked variation in the values of APTI was observed between the different plant species cultivated in the North part of the garden. These values ranged between 237.2 to 15.71. However, the maximal one was attained by Yucca elephantipes (237.2 in bed No.3) to be the highly tolerant species in the North part at all, whereas the minimal values were recorded by Thuja arientalis shrub (15.71 in bed No.2) and Delonix regia tree (15.92 in bed No.3) to become the sensitive species in this place. The other tree and shrub species scored values ranged between 27.09 and 18.03 exhibiting a moderately tolerance for air pollution load in such part. It was also noticed that Bauhinia variegata in bed No.2 gave APTI value of 25.26 and in bed No. 3 a value of 21.03, as well $F$. elastica in bed No.2 (20.17) and in bed No.4 (20.86) and F. retusa in bed No.3 and 4 (21.00), all showing a moderately tolerance against pollution irrespective of bed site, but the opposite was the right concerning Delonix regia that gave 23.53 APTI value in bed No. 2 exhibiting intermediate tolerance and 15.92 value in bed No.3 revealing a slight sensitivity to air pollution.

It is evident from APTI values registered in Table (1) that Yucca elephantipes is the highly tolerant species grown in the North part of the garden due to its production of the utmost high concentration of ascorbic acid (427.6 mg/100 g f.w.) over all other species. This may indicate that ascorbic acid content has a significant positive effect on the APTI values of the plants under study compared to the other parameters ( $\mathrm{pH}, \mathrm{RWC}$ and T. Chlo.). In this connection, Kaur and Nagpal (2017) demonstrated that Pearson's correlation coefficient matrix revealed a significant positive correlation between APTI values and ascorbic acid contents in the leaves of Alstonia scholaris, Nerium oleander, Tabernaemontana coronaria and Thevetia peruviana species during the two seasons of monsoon, while Patel and Kumar (2018) found a positive correlation between APTI and both ascorbic acid content and total chlorophylls content, and this means that both ascorbic acid content and total chlorophylls content of the leaf are responsible factors on which the APTI relies. The plants with high APTI values are tolerant to air pollution and can be used as filters/sink to mitigate air pollution, while plants with moderate and low APTI values are intermediate and sensitive to pollution and can be used as bio-indicators (Patel 
and Kumar, 2018). Presence of tolerant trees and shrubs in the industrial area can improve air quality by uptake of the gaseous and particulate pollutants. However, the high tolerance level of a specific plant species in a specific polluted area is not a general rule (Kaur and Nagpal, 2017).

Based on the values of APTI and tolerance degree listed in Table (1), the selected tree and shrub species grown in the North part of Japanese garden can be arranged in the following descending order: Yucca elephantipes > Lantana camara $>$ F. benjamina $>$ Bauhinia variegata $>$ Schinus terebenthifolius $>$ Nerium oleander $>$ Delonix regia (in bed No2) $>$ Pittosporum tobira $>F$. retusa $>F$. elastica $>$ Hibiscus rosa-sinensis $>$ Tamarix articulata $>$ Clerodendron inerme $>$ Duranta erecta $>$ D. erecta "Variegata" > Delonix regia (in bed No.3) > Thuja orientalis.

Table 1. Comparison of physio-biochemical parameters of selected plant species grown in the North part of the garden.

\begin{tabular}{|c|c|c|c|c|c|c|c|}
\hline Bed No. & Plant species & $\begin{array}{c}\text { Ascorbic } \\
\text { acid } \\
(\mathrm{mg} / 100 \\
\text { g f.w. })\end{array}$ & $\begin{array}{l}\text { R.W.C. } \\
(\%)\end{array}$ & $\mathrm{pH}$ & $\begin{array}{c}\text { Total } \\
\text { chlorophyll } \\
\text { (mg/g.f.w.) }\end{array}$ & $\begin{array}{c}\text { APTI } \\
\text { values }\end{array}$ & $\begin{array}{c}\text { Tolerance } \\
\text { degree }\end{array}$ \\
\hline \multirow{6}{*}{2} & Bauhinia variegata & $23.36 c$ & $84.58 \mathrm{e}-\mathrm{c}$ & $6.80 \mathrm{~d}-\mathrm{f}$ & $0.394 a$ & $25.26 \mathrm{bc}$ & Intermediate \\
\hline & Delonix regia & $19.52 d$ & $95.74 a-c$ & $8.81 a$ & $0.338 \mathrm{a}-\mathrm{c}$ & $23.53 c$ & Intermediate \\
\hline & Ficus elastic & $14.29 \mathrm{fg}$ & 91.49cd & $7.50 \mathrm{bc}$ & $0.208 \mathrm{a}-\mathrm{d}$ & $20.17 \mathrm{de}$ & Intermediate \\
\hline & Hibiscus rosa-sinensis & 18.36de & $79.49 h$ & $6.30 \mathrm{e}-\mathrm{g}$ & $0.223 a-d$ & 19.92d-f & Intermediate \\
\hline & Lantana camara & $22.48 \mathrm{c}$ & $96.17 a b$ & $7.51 b c$ & $0.264 a-d$ & $27.09 \mathrm{~b}$ & Intermediate \\
\hline & Thuja arientalis & $15.52 \mathrm{e}-\mathrm{g}$ & $66.09 \mathrm{jk}$ & 5.55hi & $0.317 a-c$ & $15.71 \mathrm{~g}$ & Sensitive \\
\hline \multirow{12}{*}{3} & Bauhinia variegata & $19.42 d$ & $88.82 \mathrm{de}$ & $5.90 \mathrm{gh}$ & $0.354 a-c$ & $21.03 \mathrm{~d}$ & Intermediate \\
\hline & Clerodendron inerme & $16.45 d-f$ & $79.40 \mathrm{~h}$ & $6.78 d-f$ & $0.326 \mathrm{a}-\mathrm{c}$ & 19.63d-f & Intermediate \\
\hline & Delonix regia & $13.13 \mathrm{~g}$ & $70.86 \mathrm{i}$ & $6.35 \mathrm{e}-\mathrm{g}$ & $0.380 \mathrm{ab}$ & $15.92 \mathrm{~g}$ & Sensitive \\
\hline & Duranta erecta & $14.33 \mathrm{fg}$ & $86.80 \mathrm{ef}$ & $6.50 \mathrm{~d}-\mathrm{g}$ & $0.331 a-c$ & $18.47 \mathrm{ef}$ & Intermediate \\
\hline & Duranta erecta "Vriegata & $14.23 \mathrm{fg}$ & $88.02 \mathrm{de}$ & $6.16 f-h$ & $0.323 a-c$ & $18.03 \mathrm{f}$ & Intermediate \\
\hline & Ficus benjamina & $23.41 \mathrm{c}$ & $22.30 \mathrm{~b}-\mathrm{c}$ & $6.98 c-e$ & $0.319 \mathrm{a}-\mathrm{c}$ & $26.32 b$ & Intermediate \\
\hline & Ficus retusa & $16.07 \mathrm{e}-\mathrm{g}$ & $80.40 \mathrm{gh}$ & $7.70 \mathrm{~b}$ & $0.362 \mathrm{a}-\mathrm{c}$ & $21.00 \mathrm{~d}$ & Intermediate \\
\hline & Lantana camara & $16.42 d-f$ & $95.14 a-c$ & $6.26 \mathrm{e}-\mathrm{g}$ & $0.099 \mathrm{~d}$ & 19.96d-f & Intermediate \\
\hline & Nerium oleander & $27.44 b$ & 60.001 & $6.10 \mathrm{f}-\mathrm{h}$ & $0.320 \mathrm{a}-\mathrm{c}$ & $23.61 \mathrm{c}$ & Intermediate \\
\hline & Pittosporum tobira & $23.26 c$ & $82.66 f-h$ & $6.20 f-g$ & $0.326 a-c$ & $23.44 \mathrm{c}$ & Intermediate \\
\hline & Schinus terebethifolius & $28.10 \mathrm{~b}$ & $97.16 a$ & $4.90 \mathrm{i}$ & $0.323 a-c$ & $24.39 c$ & Intermediate \\
\hline & Yucca elephantipes & $427.60 \mathrm{a}$ & $69.02 \mathrm{ij}$ & $5.20 \mathrm{i}$ & $0.185 b-d$ & $237.2 a$ & Highly tolerant \\
\hline \multirow{3}{*}{4} & Ficus elastic & 18.55de & $83.58 f-h$ & $6.40 \mathrm{e}-\mathrm{g}$ & $0.344 a-c$ & $20.86 d$ & Intermediate \\
\hline & Ficus retusa & $16.07 \mathrm{e}-\mathrm{g}$ & $80.40 \mathrm{gh}$ & $7.70 \mathrm{~b}$ & $0.362 a-c$ & $21.00 \mathrm{~d}$ & Intermediate \\
\hline & Tamarix articulate & 18.47de & $63.69 \mathrm{kl}$ & $7.16 \mathrm{~b}-\mathrm{d}$ & $0.166 \mathrm{~cd}$ & 19.90d-f & Intermediate \\
\hline
\end{tabular}

\section{2- The middle part of the garden:}

A similar response to that of plant species grown in the North part against air pollution prevailing in the atmosphere of Helwan industrial city was occurred as well concerning those grown in the Middle part that was represented by beds No. 5, 6 and 8, as a significant differences in the means of ascorbic acid content, 
RWC, leaf extract pH and total chlorophyll content were observed between the various tree and shrub species sampled from such place (Table, 2 ).

The highest concentration of ascorbic acid was also gained in this part of garden by Yucca elephantipes plants, which significantly raised such constituent in their leaves to $283.1 \mathrm{mg} / 100 \mathrm{~g}$ f.w. The second rank was occupied by Cassia nodosa ( $81.46 \mathrm{mg} / 100 \mathrm{~g} \mathrm{f.w.}$ ) and the third one by Cassia fistula $(59.37 \mathrm{mg} / 100$ $g$ f.w.) with significant differences in between. The lowest concentration, however achieved by Hibiscus rosa-sinensis (12.6), Euphorbia pulcherrima (13.11) and then both Kigelia pinnata (14.27) and Ficus elastica "decora" (14.40) with no significant differences among themselves, while all the other species gave values ranged between 38.39 to 16.31 (mg/100 g f.w.) with various significant levels between themselves.

Marked variables were also noticed in the matter of RWC (\%) of the different plant species selected from this part. The highest percent of RWCs were acquired by Ficus elastica "decora" (96.84\%), Clerodendron inerme (96.56 \%), Delonix regia (95.36 \%), F. benjamina (94.43\%), Euphorbia pulcherrima (92.91 $\%)$ and Strelitzia reginae (92.53\%) plant species with non-significant differences in between, but were significantly reduced to $91.93,91.19$ and $90.40 \%$ in the leaves of Thuja orientalis, Yucca elephantipes and Ziziphus spina-christi species, respectively. The other species attained also high RWCs ranged between 89.91 to $80.95 \%$ with the inferiority of Tipuana speciosa, which gave only $71.55 \%$ of RWC in its leaves. In general, most plant species grown in the middle part of Japanese garden possessed higher relative water content than species grown in the other parts.

The leaf extract $\mathrm{pH}$ of $F$. benjamina (7.86), F. benghalensis (7.17) and Plumeria alba (7.0) plant species were either neutral or significantly tended to be alkaline, showing its unaffected by air pollutants in such place, whilst the other species were variously affected giving acidic leaf extract had $\mathrm{pH}$ values less than 6.5 in most species. However, the highest acidity was fulfilled by Dendrocalamus giganteus leaves which scored $\mathrm{pH}$ value of 5.0 and then Yucca elephantipes leaves that gave $\mathrm{pH}$ mean of 5.41. It is clear from $\mathrm{pH}$ data presented in Table (2) that $\mathrm{pH}$ differences among various plants cultivated in this part were significant.

Besides, data in Table (2) imply to a pronounced variance in the leaf content of total chlorophyll among the different trees and shrubs grown in the middle part of the garden. The level of variance was insignificant between the tolerant species and some intermediate ones, except for Yucca elephantipes, in which total chlorophyll content was significantly reduced to $0.271 \mathrm{mg} / \mathrm{g}$ f.w. compared 
to some tolerant and intermediate other species, although it is categorized as a highly tolerant to air pollution in such place of the garden. Total chlorophyll content reached to the maximum in the leaves of $F$. benghalensis $(0.353 \mathrm{mg} / \mathrm{g} \mathrm{f.w.}$ ), meanwhile reached to the minimum in the leaves of Hibiscus rosa-sinensis $(0.199 \mathrm{mg} / \mathrm{g}$ f.w.) and ranged for other species between 0.227 and 0.344 (mg/g f.w.) with various significance levels in between.

According to APTI values and tolerance levels of the different trees and shrubs grown in the middle part recorded in Table (2), there weren't any plant sensitive to air pollution in such part. So, they could be arrange in this order: Yucca elephantipes $>$ Cassia nodosa $>C$. fistula $>$ F. benjamina $>$ Ziziphus spinachristi $>$ Delonix regia $>$ Schinus molle $>$ Plumeria alba $>$ Cycas revoluta $>$ Thuja orientalis $>$ Strelitzia reginae $>$ Clerodendron inerme $>F$. benghalensis $>$ Washingtonia filifera > Tipuana speciosa > F. lyrata > Duranta erecta "Veriegata" $>$ F. elastica "decora" > Kigelia pinnata > Dendrocalamus giganteus $>$ Euphorbia pulcherrima > Hibiscus rosa-sinensis.

The aforementioned results could be discussed and interpretted as done before in case of the selected plants grown in the North part. These results are in the same line with that observed by Dwivedi and Tripathi (2007) on Ricinus communis and Lepidium sativum, Tripathi et al., (2009) on Alstonia scholaris, Azadirachta indica, Bauhinia variegata, Cassia simea, Ficus rumphii, Grivellea robusta and Saraca indica, Begum and Harikrishna (2010) on Ficus religiosa, Azadirachta indica and Pongamia pinnata and Chandawat et al., (2011) who expressed an order of tolerance, in which Ficus benghalensis exhibited the highest APTI values at the different polluted sites, and followed by F. religiosa > F. glomerata > Azadirachta indica > Polyalthia longifolia. Furthermore, Krishnaveni et al., (2013) inferred that Nerium oleander has APTI value of 16.65 and identified as intermediate tolerance species, whereas $F$. benghalensis, Psidium guajava, Spathodea campanulata and Opuntia ficus-indica had APTI scores of 15.92, 15.41, 9.92 and 9.74 were identified as sensitive species. Bora and Joshi (2014) on 6 plant species, found that the order of tolerance index was as follows: Saraca indica (13.71), Azadirachta indica (12.98), Shorea robusta (12.64), Eucalyptus sp. (12.61), F. religiosa (12.61) and Tectona grandis (12.33). On 4 plant species selected from transportation and industrial areas, Akilan and Nandhakumar (2016) noticed that Nerium oleander recorded higher APTI value and exhibited more tolerance than Tamarindus indica, Azadirachta indica and Pungamia pinnata. 
Table 2. Comparison of physio-biochemical parameters of selected plant species grown in the Middle part of the garden.

\begin{tabular}{|c|c|c|c|c|c|c|c|}
\hline Bed No. & Plant species & $\begin{array}{c}\text { Ascorbic } \\
\text { acid } \\
\text { (mg/100 g } \\
\text { f.w.) }\end{array}$ & $\begin{array}{c}\text { R.W.C. } \\
\text { (\%) }\end{array}$ & $\mathrm{pH}$ & $\begin{array}{c}\text { Total } \\
\text { chlorophyll } \\
\text { (mg/g.f.w.) }\end{array}$ & $\begin{array}{c}\text { APTI } \\
\text { values }\end{array}$ & $\begin{array}{c}\text { Tolerance } \\
\text { degree }\end{array}$ \\
\hline 5 & Dendrocalamus giganteus & $17.78 \mathrm{gh}$ & $85.23 \mathrm{i}-\mathrm{k}$ & $5.00 \mathrm{~m}$ & $0.255 \mathrm{~d}-\mathrm{g}$ & 17.871 & Intermediate \\
\hline \multirow{19}{*}{6} & Cassia fitula & $59.37 c$ & $87.80 \mathrm{~g}-\mathrm{j}$ & $6.50 f$ & $0.333 a-c$ & $49.28 c$ & Tolerant \\
\hline & Cassia nodosa & $81.46 \mathrm{~b}$ & $80.95 i$ & $5.85 \mathrm{k}$ & $0.311 a-d$ & $58.28 \mathrm{~b}$ & Tolerant \\
\hline & Clerodendron inerme & 17.74gh & $96.56 a$ & $6.19 \mathrm{i}$ & $0.265 d-f$ & $21.11 \mathrm{~h}-\mathrm{j}$ & Intermediate \\
\hline & Cycas revolute & $20.21 \mathrm{~g}$ & $83.12 \mathrm{kl}$ & $6.57 \mathrm{e}$ & $0.280 \mathrm{c}-\mathrm{f}$ & $22.15 \mathrm{~h}$ & Intermediate \\
\hline & Delonix regia & $30.17 e$ & $95.36 a-c$ & $5.99 \mathrm{j}$ & $0.227 \mathrm{fg}$ & $28.29 d-f$ & Intermediate \\
\hline & Euphorbia pulcherrima & $13.11 \mathrm{j}$ & 92.91a-e & $5.84 \mathrm{k}$ & $0.305 a-e$ & 17.351 & Intermediate \\
\hline & Ficus benghalensis & $16.31 \mathrm{hi}$ & $88.31 f-j$ & $7.17 \mathrm{~b}$ & $0.353 a$ & $21.10 \mathrm{~h}-\mathrm{j}$ & Intermediate \\
\hline & Ficus benjamina & $24.91 f$ & $94.43 a-d$ & $7.86 a$ & $0.303 a-e$ & 29.78de & Tolerant \\
\hline & Ficus elastica "decora" & $14.40 \mathrm{ij}$ & $96.84 a$ & $6.42 \mathrm{~g}$ & $0.273 c-f$ & $19.59 \mathrm{jk}$ & Intermediate \\
\hline & Ficus lyrata & $17.45 \mathrm{gh}$ & $84.84 \mathrm{j}-\mathrm{I}$ & $6.40 \mathrm{~g}$ & $0.315 \mathrm{a}-\mathrm{d}$ & $20.20 \mathrm{ij}$ & Intermediate \\
\hline & Kigelia pinnata & $14.27 \mathrm{ij}$ & $89.46 \mathrm{e}-\mathrm{i}$ & $6.26 \mathrm{~h}$ & $0.344 a b$ & $18.36 \mathrm{kl}$ & Intermediate \\
\hline & Plumeria alba & $24.67 f$ & $88.21 f-j$ & $7.00 \mathrm{c}$ & $0.299 \mathrm{a}-\mathrm{e}$ & $26.82 f$ & Intermediate \\
\hline & Schinus molle & $29.73 e$ & $86.28 \mathrm{~h}-\mathrm{k}$ & $6.16 \mathrm{i}$ & $0.295 a-e$ & 27.82ef & Intermediate \\
\hline & Strelitzia reginae & $18.40 \mathrm{gh}$ & 92.53a-f & $6.30 \mathrm{~h}$ & $0.272 \mathrm{c}-\mathrm{f}$ & $21.34 \mathrm{~h}-\mathrm{j}$ & Intermediate \\
\hline & Tipuana speciosa & $18.59 \mathrm{gh}$ & $71.55 \mathrm{~m}$ & $6.77 d$ & $0.297 a-e$ & $20.29 \mathrm{ij}$ & Intermediate \\
\hline & Thuja orientalis & $19.85 \mathrm{~g}$ & $91.93 \mathrm{~b}-\mathrm{g}$ & $6.14 \mathrm{i}$ & $0.246 \mathrm{e}-\mathrm{g}$ & 21.87hi & Intermediate \\
\hline & Washingtonia filfera & $18.35 \mathrm{gh}$ & $83.33 \mathrm{kl}$ & $6.29 \mathrm{~h}$ & $0.348 a b$ & $20.51 \mathrm{~h}-\mathrm{j}$ & Intermediate \\
\hline & Yucca elephantipes & $283.1 \mathrm{a}$ & $91.19 \mathrm{c}-\mathrm{g}$ & 5.411 & $0.271 c-f$ & $169.9 a$ & Highly tolerant \\
\hline & Ziziphus spina-christi & $30.11 \mathrm{e}$ & $90.40 \mathrm{~d}-\mathrm{h}$ & $6.40 \mathrm{~g}$ & $0.316 \mathrm{a}-\mathrm{d}$ & 29.26de & Intermediate \\
\hline & Duranta erecta "Variegata" & $16.32 \mathrm{hi}$ & $89.91 \mathrm{e}-\mathrm{h}$ & $6.25 \mathrm{~h}$ & $0.287 b-f$ & $19.65 \mathrm{jk}$ & Intermediate \\
\hline & Hibiscus rosa-sinensis & $12.60 \mathrm{j}$ & $88.13 f-j$ & $6.50 f$ & $0.199 \mathrm{~g}$ & $17.25 I$ & Intermediate \\
\hline
\end{tabular}

\section{3- The South part of the garden:}

This part included beds No. 9, 10 and 11 (Photo., 1).

The different physio-biochemical traits of the selected plant species cultivated in this place revealed also clear variances with significant differences in most instances (Table, 3). In this respect, ascorbic acid content in the leaves of plants grown in such area varied from 31.68 to $10.61 \mathrm{mg} / 100 \mathrm{~g}$ f.w. However, the utmost high concentration of this constituent was found in the leaves of Cassia fistula (31.68 $\mathrm{mg} / 100 \mathrm{~g}$ f.w.) bed 11, followed by Delonix regia (29.39) bed 10 and Washingtonia 
filifera (29.19) bed 9 with non-significant differences among them, whereas the utmost low concentration was found in the leaves of Acalypha marginata that scored only $10.61 \mathrm{mg} / 100 \mathrm{~g}$ f.w bed 10 . The other plant species gave concentrations ranged between 26.01 and $15.59 \mathrm{mg} / 100 \mathrm{~g}$ f.w. with various significancy levels in between. It is well known that plants had high ascorbic acid are more tolerant to air pollutants (Kumari and Deswal, 2017).

Likewise, the results of relative water content (RWC \%) increased to the maximum in Acalypha marginata (94.62 \%) and Delonix regia (92.57\%) leaves, but decreased to the minimum in the leaves of two moderately tolerant shrubs; Dodonaea viscosa $(60.64 \%)$ and Thuja orientalis (61.15\%) with non-significant differences among them. In the other trees and shrubs sampled from this part, RWC \% ranged from 65.52 to $90.59 \%$ with significant differences between species. Similar trend was also obtained by Kumari and Deswal (2017) who decided that RWC of Plumeria sp. and Delonix regia was the highest, but decreased to the lowest in Polyalthia longifolia (49\%).

Values of leaf extract pH in Ficus sycomorus (7.71), F. elastica (7.26) and Lantana camara (7.17) tended toward alkalinity, whereas in other tree and shrub species deviated to acidity, especially Washigtonia filifera, Cassia fistula, Eucalyptus camaldulensis and Clerodendron inerme species that attained $\mathrm{pH}$ values of 5.53, $5.54,5.70$ and 5.75 , respectively. Reducing $\mathrm{pH}$ value in some plant species may be ascribed to presence of acidic pollutants. Low pH of leaf extract showed good correlation with sensitivity to air pollution and may reduces photosynthetic process in plants (Yan and Hui, 2008). In this regard, Singh and Rao (1983) mentioned that pH of leaf reflects the acidic and alkaline nature as a response to a sensitivity of air pollution. On 5 tree species, Kumari and Deswal (2017) found that Ficus religiosa was the most alkaline ( $\mathrm{pH}:$ 7.54) among all, while Plumeria sp. (6.5) and Azadirachta indica (6.61) was the most acidic.

Concerning the total chlorophylls content, data in Table (3) revealed that a slight variation was occurred among the different species of plants grown in this part as they all gave closely near concentrations with non-significant differences in between, except for Eucalyptus camaldulensis that contained $0.321 \mathrm{mg} / \mathrm{g}$ f.w. and Grevillea robusta that possessed $0.318 \mathrm{mg} / \mathrm{g}$ f.w. in their leaves, while the lowest chlorophyll content was found in the leaves of Cassia fistula plants sampled from bed No.9 (0.177 mg/g f.w.), although such plant gave significantly higher content (0.297 $\mathrm{mg} / \mathrm{g}$ f.w.) when grown in bed No. 11 . That was not true for Delonix regia, which sampled from beds No. 10 and 11, as it gave a near content of chlorophyll. A similar response was also obtained by Kumari and Deswal (2017) on Delonix regia, Ficus 
religiosa and Plumeria sp. and Salaa and Al-Kawaz (2017) who reported that chlorophyll content ranged from 1.31-2.41 mg/g f.w. in Conocarpus lancifolius of site 1 , but ranged from $0.26-0.49 \mathrm{mg} / \mathrm{g}$ in site 2 , while in Dodonaea viscosa in site 1 , it ranged from $0.83-1.75 \mathrm{mg} / \mathrm{g}$ and in site 2 from $0.28-0.70 \mathrm{mg} / \mathrm{g}$. This indicates that productivity was higher in site 1 compared with site 2 for the two species. This may be attributed to the adversely effect of acidic $\mathrm{pH}$ of the leaf sap.

Table 3. Comparison of physio-biochemical parameters of selected plant species grown in the South part of the garden.

\begin{tabular}{|c|c|c|c|c|c|c|c|}
\hline Bed No. & Plant species & $\begin{array}{c}\text { Ascorbic } \\
\text { acid } \\
\text { (mg/100 g } \\
\text { f.w.) }\end{array}$ & $\begin{array}{c}\text { R.W.C. } \\
(\%)\end{array}$ & $\mathrm{pH}$ & $\begin{array}{c}\text { Total } \\
\text { chlorophyll } \\
\text { (mg/g.f.w.) }\end{array}$ & $\begin{array}{c}\text { APTI } \\
\text { values }\end{array}$ & $\begin{array}{c}\text { Tolerance } \\
\text { degree }\end{array}$ \\
\hline \multirow{4}{*}{9} & Cassia fistula & $16.43 \mathrm{ef}$ & $65.52 \mathrm{~g}$ & $5.54 j$ & $0.177 \mathrm{~d}$ & $15.94 \mathrm{~h}$ & Sensitive \\
\hline & Ficus elastica & $18.64 d-f$ & $90.14 b c$ & $7.26 \mathrm{~b}$ & $0.298 a-c$ & 23.10de & Intermediate \\
\hline & Grevillea robusta & 19.18de & $81.06 \mathrm{e}$ & $6.16 \mathrm{~g}$ & $0.318 a$ & $20.53 \mathrm{fg}$ & Intermediate \\
\hline & Washingtonia filfera & $29.19 a$ & $90.59 \mathrm{bc}$ & $5.53 \mathrm{j}$ & $0.309 a-c$ & $26.10 \mathrm{bc}$ & Intermediate \\
\hline \multirow{6}{*}{10} & Acalypha marginata & $10.61 \mathrm{~g}$ & $94.62 a$ & $6.06 \mathrm{~h}$ & $0.308 a-c$ & $15.99 \mathrm{~h}$ & Sensitive \\
\hline & Cassia nodosa & $16.39 \mathrm{ef}$ & $80.96 \mathrm{e}$ & $6.20 \mathrm{~g}$ & $0.315 \mathrm{ab}$ & $24.83 \mathrm{~cd}$ & Intermediate \\
\hline & Delonix regia & 29.39a & $92.57 a b$ & $6.79 d$ & $0.273 a-c$ & $30.02 a$ & Tolerant \\
\hline & Eucalyptus camaldulensis & $20.48 \mathrm{~cd}$ & $72.73 \mathrm{f}$ & $5.70 \mathrm{i}$ & $0.321 \mathrm{a}$ & $19.56 \mathrm{~g}$ & Intermediate \\
\hline & Lantana camara & $26.01 \mathrm{~b}$ & $71.53 \mathrm{f}$ & 7.17c & $0.251 \mathrm{c}$ & $26.46 \mathrm{bc}$ & Intermediate \\
\hline & Nerium oleander & $23.36 \mathrm{bc}$ & $65.97 \mathrm{~g}$ & $6.18 \mathrm{~g}$ & $0.292 a-c$ & 21.72ef & Intermediate \\
\hline \multirow{6}{*}{11} & Cassia fistula & $31.68 \mathrm{a}$ & $88.28 \mathrm{~cd}$ & $6.75 d$ & $0.297 a-c$ & $31.15 a$ & Tolerant \\
\hline & Clerodendron inerme & $15.59 f$ & $81.37 \mathrm{e}$ & $5.75 \mathrm{i}$ & $0.288 \mathrm{a}-\mathrm{c}$ & $17.54 \mathrm{~h}$ & Intermediate \\
\hline & Delonix regia & $23.48 \mathrm{bc}$ & $83.39 \mathrm{e}$ & $6.60 \mathrm{e}$ & $0.289 a-c$ & $24.51 \mathrm{~cd}$ & Intermediate \\
\hline & Dodonaea viscosa & $16.39 \mathrm{ef}$ & $60.64 \mathrm{~h}$ & $6.36 f$ & $0.312 a b$ & $17.00 \mathrm{~h}$ & Intermediate \\
\hline & Ficus sycomorus & $23.41 \mathrm{bc}$ & $86.64 \mathrm{~h}$ & $7.71 \mathrm{a}$ & $0.255 \mathrm{bc}$ & $27.29 \mathrm{~b}$ & Intermediate \\
\hline & Thuja orientalis & $16.45 \mathrm{ef}$ & $61.15 \mathrm{~h}$ & $6.40 f$ & $0.277 a-c$ & $17.09 \mathrm{~h}$ & Intermediate \\
\hline
\end{tabular}

Due to the variability observed in ascorbic acid content, RWC, pH and total chlorophylls content, APTI values and tolerance levels were also varied (Table, 3). Delonix regia (in bed No.10) and Cassia fistula (in bed No.11) are considered tolerant, as they gave APTI values of 30.02 and 31.15, respectively, whereas Cassia fistula in bed No. 9 (15.94) and Acalypha marginata in bed No. 10 (15.99) were sensitive. The rest plants, however were moderately tolerant. On the basis of calculated APTI and the corresponding tolerance degrees indicated in Table (3), the tree and shrub species in this part can be arranged in this order: Cassia fistula (in bed No. 11) > Delonix regia > Ficus sycomorus $>$ Lantana camara $>$ Washingtonia filifera $>$ Cassia nodosa $>$ F. elastica $>$ Nerium oleander $>$ Grevillea robusta $>$ Eucalyptus camaldulensis $>$ Thuja orientalis > Dodonaea viscosa > Acalypha marginata > Cassia fistula (in bed No. 9).

The previous results may be discussed and explained as stated before in case of selected plant species grown in the North and middle parts of the garden. 
A. COMPARISON OF DIFFERENT SPECIES GROWN IN A SPECIFIC PART OF THE GARDEN

\section{4- The East part of the garden:}

This part lies adjacent to Fayzi Basha St. from East direction, and involved only the bed No.12.

It is obvious from data averaged in Table (4) that different plant species cultivated in such part showed considerable variations in their susceptibility to air pollution prevailing in atmosphere of the industrial Helwan City, giving different means of ascorbic acid content, RWCs, leaf extract pH and total chlorophyll content. In general, ascorbic acid content ranged between $26.50 \mathrm{mg} / 100 \mathrm{~g}$ f.w. attained by $F$. benghalensis to $14.91 \mathrm{mg} / 100 \mathrm{~g}$ f.w. scored by F. microcarpa "Hawaii". High ascorbic acid content is usually associated with tolerant plant species and vice-versa. Relative water content was more than $83 \%$ in most plant species found in this place, but it was increased in the leaves of Codiaeum variegatum to $93.25 \%$ and $F$. benghalensis to $91.30 \%$, however, decreased to $52.57 \%$ in the leaves of Hibiscus rosa-sinensis. The RWC usually affects the leaf extract $\mathrm{pH}$, the higher RWC the more dilute of the sap (Salaa and Al-Kawaz, 2017). The pH values were more than 7 in the leaf extract of F. microcarpa "Hawaii" (7.52) and Lantana camara (7.45), but turned to acidity in other plant species to be slightly less than 7, except for Duranta erecta that recorded the highest acidity of leaf sap (4.21) relative to other species. Although total chlorophylls content varied from species to another, the differences between them were not significant. However, the highest content was found in the leaves of Lantana camara ( $0.260 \mathrm{mg} / \mathrm{g}$ f.w.), followed by F. benghalensis $(0.254 \mathrm{mg})$.

The previous 4 factors were combined to calculate the values of pollution tolerance index, which were ranged as shown in Table (4) from 17.09 to 27.56. These values indicate that all the eight plants selected from this part are intermediates/moderately tolerant to air pollution according to APTI-scale suggested by Begum and Harikrishna (2010), as APTI values are restricted between 17-29 (see APTI scale).

These gains could be discussed and interpreted as previously shown in case of selected plants grown in the North part of the garden.

Table 4. Comparison of physio-biochemical parameters of selected plant species grown in the East part of the garden.

\begin{tabular}{|c|c|c|c|c|c|c|c|}
\hline Bed No. & Plant species & $\begin{array}{c}\text { Ascorbic acid } \\
\text { (mg/100 g } \\
\text { f.w.) }\end{array}$ & $\begin{array}{l}\text { R.W.C. } \\
(\%)\end{array}$ & $\mathrm{pH}$ & $\begin{array}{c}\text { Total } \\
\text { chlorophyll } \\
\text { (mg/g.f.w.) }\end{array}$ & $\begin{array}{c}\text { APTI } \\
\text { values }\end{array}$ & $\begin{array}{c}\text { Tolerance } \\
\text { degree }\end{array}$ \\
\hline \multirow{8}{*}{12} & Breynia disticha & $15.02 d$ & $88.51 b c$ & $6.57 a b$ & 0.163 & $18.81 d$ & Intermediate \\
\hline & Codiaeum variegatum & $18.68 \mathrm{c}$ & $93.25 a$ & $6.86 a b$ & 0.167 & $22.45 b$ & Intermediate \\
\hline & Cycas revolute & $17.20 \mathrm{c}$ & $83.18 \mathrm{~d}$ & $6.92 a b$ & 0.123 & $20.43 c$ & Intermediate \\
\hline & Duranta erecta & $21.18 \mathrm{~b}$ & $87.28 \mathrm{c}$ & $4.21 \mathrm{c}$ & 0.11 & $22.11 b$ & Intermediate \\
\hline & Ficus benghalensis & $26.50 a$ & 91.30ab & $6.70 a b$ & 0.254 & $27.56 a$ & Intermediate \\
\hline & Ficus microcarpa "Hawii" & $14.91 d$ & $89.01 b c$ & $7.52 \mathrm{a}$ & 0.172 & $20.36 c$ & Intermediate \\
\hline & Hibiscus rosa-sinensis & $18.63 c$ & $52.57 e$ & $6.22 b$ & 0.132 & $17.09 \mathrm{e}$ & Intermediate \\
\hline & Lantana camara & $17.62 \mathrm{c}$ & $83.21 d$ & $7.45 a$ & 0.26 & $21.91 b$ & Intermediate \\
\hline
\end{tabular}




\section{5- The West part of the garden:}

This part is bounded by Dr Mostafa Safwat St. from the West, and included bed No. 1 at the North West portion and bed No.7 at the South west portion, beside the main entrance of the garden that lies between the two beds mentioned above (Photo, 1).

A similar response to that obtained in the North, Middle and South parts of the garden was also occurred in such part, as the means of physio-biochemical characteristics were markedly varied from species to other, with few exceptions in some cases. So, data provided in Table (5) clear that ascorbic acid content varied from 14.05 (mg/100 g f.w.) in Hibiscus rosa-sinensis and $14.98 \mathrm{mg} / 100 \mathrm{~g}$ in $F$. benghalensis to $45.88 \mathrm{mg} / 100 \mathrm{~g}$ in Delonix regia (bed $\mathrm{No} .1$ ) and $41.45 \mathrm{mg} / 100 \mathrm{~g}$ in Pinus halepensis (bed No. 1), while for the other species, it was ranged between 15.78 to $28.24 \mathrm{mg} / 100 \mathrm{~g}$. With respect to RWC \%, it reached maximum in the leaves of Acalypha marginata (96.41), followed by Delonix regia in bed No. 1 (95.89), Brachychiton porpulenum (95.67), Duranta erecta "Variegata" (94.64), F. microcarpa "Hawaii" in bed. No.1 (94.61) and F. elastica (94.47), but was minimum in the leaves of Araucaria heterophylla (55.57) and medium in the rest species (64.85 to 92.62). Regarding $\mathrm{pH}$ values, F. elastica, F. microcarpa "Hawaii" and F. retusa scored above neutral values ranged between 7.34 and 7.80 , whereas other species resulted acidic leaf extracts varied from 4.15 to 6.82 with significant differences in most instances. The highest acidity was found due to Pinus canariensis grown in bed No.7, that gave $\mathrm{pH}$ of 4.15. Great differences were also observed in the means of total chlorophyll among plant species selected from such place. The highest content was recorded by Delonix regia $(0.335 \mathrm{mg} / \mathrm{g})$, Lantana camara $(0.312 \mathrm{mg} / \mathrm{g})$, Thuja orientalis $(0.311$ $\mathrm{mg} / \mathrm{g}), H$. rosa-sinensis $(0.309 \mathrm{mg} / \mathrm{g})$, F. elastica $(0.307 \mathrm{mg} / \mathrm{g})$, Bauhinia variegata $(0.302 \mathrm{mg} / \mathrm{g})$, F. retusa $(0.296 \mathrm{mg} / \mathrm{g})$, F. microcarpa "Hawaii" $(0.287 \mathrm{mg} / \mathrm{g})$ and $F$. benghalensis $(0.282 \mathrm{mg} / \mathrm{g})$ with non-significant differences in between, while the lowest contents were noticed in the leaves of Brachychiton porpulenum $(0.148 \mathrm{mg} / \mathrm{g})$ and F. microcarpa "Hawaii" in bed No.1 $(0.143 \mathrm{mg} / \mathrm{g})$.

According to APTI values, tree and shrub species grown in this part of the garden can be scaled-down in this order: Delonix regia > Pinus halepensis > Lantana camara $>$ Thuja orientalis $>$ Hibiscus rosa sinensis $>$ F. elastica $>$ Bauhinia variegata $>$ F. retusa > F. microcarpa "Hawaii" > Ficus benghalensis $>$ Pinus halepensis $>$ Acalypha marginata $>$ Araucaria heterophylla $>$ Punica granatum $>$ Pius canariensis $>$ Brachychiton propulenum. 
A. COMPARISON OF DIFFERENT SPECIES GROWN IN A SPECIFIC PART OF THE GARDEN

Table 5. Comparison of physio-biochemical parameters of selected plant species grown in the West part of the garden.

\begin{tabular}{|c|c|c|c|c|c|c|c|}
\hline Bed No. & Plant species & $\begin{array}{c}\text { Ascorbic } \\
\text { acid } \\
\text { (mg/100 g } \\
\text { f.w.) }\end{array}$ & $\begin{array}{c}\text { R.W.C. } \\
(\%)\end{array}$ & $\mathrm{pH}$ & $\begin{array}{c}\text { Total } \\
\text { chlorophyll } \\
\text { (mg/g.f.w.) }\end{array}$ & $\begin{array}{c}\text { APTI } \\
\text { values }\end{array}$ & $\begin{array}{c}\text { Tolerance } \\
\text { degree }\end{array}$ \\
\hline \multirow{9}{*}{1} & Acalypha marginata & 23.60de & $96.41 a$ & $6.20 d-f$ & $0.267 \mathrm{~b}-\mathrm{e}$ & 24.91c & Intermediate \\
\hline & Araucaria heterophylla & $15.78 \mathrm{fg}$ & $55.57 \mathrm{j}$ & $6.34 d-f$ & $0.232 \mathrm{~d}-\mathrm{f}$ & $15.93 \mathrm{~g}$ & Sensitive \\
\hline & Delonix regia & $45.88 a$ & $95.89 a b$ & $6.40 \mathrm{~d}-\mathrm{f}$ & $0.335 a$ & $40.48 a$ & Tolerant \\
\hline & Duranta erecta "Variegata" & $16.41 \mathrm{fg}$ & $94.64 a b$ & $6.60 c-e$ & $0.241 \mathrm{c}-\mathrm{f}$ & $21.69 d$ & Intermediate \\
\hline & Ficus microcarpa "Hawii" & $17.80 f$ & $94.61 a b$ & $7.80 a$ & $0.143 \mathrm{~g}$ & $21.82 \mathrm{~d}$ & Intermediate \\
\hline & Hibiscus rosa-sinensis & $14.05 \mathrm{~g}$ & $87.49 \mathrm{~d}-\mathrm{f}$ & $6.80 \mathrm{~b}-\mathrm{d}$ & $0.309 a b$ & $18.74 \mathrm{ef}$ & Intermediate \\
\hline & Pinus halepensis Mill. & $41.45 b$ & $72.35 \mathrm{~h}$ & $5.71 \mathrm{f}$ & $0.193 \mathrm{fg}$ & $31.71 \mathrm{~b}$ & Tolerant \\
\hline & Punica granatum & $18.57 f$ & $78.13 \mathrm{~g}$ & $6.35 d-f$ & $0.214 \mathrm{ef}$ & 20.00d-f & Intermediate \\
\hline & Lantana camara & 25.10de & $90.01 c-e$ & $6.30 \mathrm{~d}-\mathrm{f}$ & $0.312 \mathrm{ab}$ & $25.63 c$ & Intermediate \\
\hline \multirow{9}{*}{7} & Bauhinia variegate & $28.24 c$ & $86.47 \mathrm{ef}$ & $6.15 d-f$ & $0.302 a-c$ & $26.86 c$ & Intermediate \\
\hline & Brachychiton porpulenum & $25.63 d$ & $95.67 a b$ & 5.87ef & $0.148 \mathrm{~g}$ & $24.99 c$ & Intermediate \\
\hline & Delonix regia & $16.41 \mathrm{fg}$ & $90.80 \mathrm{~cd}$ & $6.78 b-d$ & $0.245 c-f$ & 20.61de & Intermediate \\
\hline & Ficus benghalensis & $14.98 \mathrm{~g}$ & $92.62 \mathrm{bc}$ & $6.82 \mathrm{~b}-\mathrm{d}$ & $0.282 a-d$ & 19.90d-f & Intermediate \\
\hline & Ficus elastica & $15.82 \mathrm{fg}$ & $94.47 a b$ & $7.50 \mathrm{ab}$ & $0.307 a b$ & $21.80 \mathrm{~d}$ & Intermediate \\
\hline & Ficus microcarpa "Hawii" & $22.51 \mathrm{e}$ & $85.47 f$ & 7.41ab & $0.287 a-d$ & $25.88 \mathrm{c}$ & Intermediate \\
\hline & Ficus retusa & $22.48 \mathrm{e}$ & $87.23 \mathrm{ef}$ & 7.34a-c & $0.296 a-c$ & $25.89 \mathrm{c}$ & Intermediate \\
\hline & $\begin{array}{l}\text { Pius canariensis } \\
\text { Sweet ex. K. Spreng }\end{array}$ & $22.40 \mathrm{e}$ & $81.19 \mathrm{~g}$ & $4.15 g$ & $0.272 b-e$ & $18.03 f$ & Intermediate \\
\hline & Thuja orientalis & 23.31de & $64.85 \mathrm{i}$ & 5.89ef & $0.311 \mathrm{ab}$ & $20.96 \mathrm{~d}$ & Intermediate \\
\hline
\end{tabular}

From the aforestated results, it is concluded that each tree and shrub species in each part of the garden exhibited a different behaviour against air pollution prevailing in every part than the other species, i.e. each species gave individual response than the other species under air pollution conditions of the same place. So, it can be recommend to plant Yucca elephantipes, F. benjamina, Bauhinia variegata and Lantana camara species in the North part, Yucca elephantipes, Cassia nodosa, C. fistula and F. benjamina in the Middle part; Cassia fistula, Delonix regia, Ficus sycomorus, Lantana camara and Washingtonia filifera in the South part; Ficus benghalensis, Codiaeum variegata (Croton), Duranta erecta and Lantana camara in the East part, and Delonix regia (Poinciana), Pinus halepensis, Bauhinia variegata, Ficus retusa (F. nitida), F. microcarpa "Hawii", Lantana camara and Brachychiton porpulenum in the west part as the most suitable ornamentals for air pollution load in the cited parts of Japanese garden.

\section{REFERENCES}

1. Akilan, M. and Nandhakumar, S. 2016. Air pollution tolerance index of selected plants in industrial and urban areas of Vellore district. Agric. Sci. Digest, 36 (1): 66-68.

2. Andrew, B. 2005. Cairo: A Cultural and Literary History. Signal Books, P.196. 
3. Babu, G. B.; parveen, S. N.; Kumar, K. N. and Reddy, M. S. 2013. Evaluation of air polluation tolerance indices of plant species growing in the vicinity of cement industry and Yogi Vemana Univ. Campus. Indian J. Advances in Chem. Sci., 2 (1): 16-20.

4. Bailey, L. H. 1976. Hortus Third, Macmillan Publishing Co., Inc., 866 Third Avenue, New York, N.Y. 10022.1290 pp.

5. Begum, A. and Harikrishna, S. 2010. Evaluation of some tree species to absorb air pollution in three industrial locations of south Bengaluru, India. E.Journal of Chemitry, 7 (1): 151-156.

6. Bora, M. and Joshi, M. 2014. A study on variation in biochemical aspects of different tree species with tolerance and performance index. Ecoscan, 9 (1): 59-63.

7. Chandawat, D.K.; Verma, P. U. and Solanki, H. A. 2011. Air pollution tolerance index (APTI) of tree species at cross road of Ahmedabad city. Life Sci. Leaflets, 20: 935-943.

8. Dwivedi, A.K. and Tripathi, B. D. 2007. Pollution tolerance and distribution pattern of plants in surrounding area of coal-fired industries. J. Environ. Biol., 28: 257-263.

9. Dwivedi, A.K.; Tripathi, B. D. and Shashi, A. 2008. Effect of ambient air sulphur dioxide on sulphate accumulation in plants. J. Environ. Biol., 29 (3): 377-379.

10. Jyothi, S.J. and Jaya, D. S. 2010. Evaluation of air pollution tolerance index of selected plant species along roadsides in Thiruvananthapuram, Kerala. J. Environ. Biol., 31: 379386.

11. Kaur, M. and Nagpal, A. K. 2017. Evaluation of air pollution tolerance index and anticipated performance index of plants and their application in development of green space along the urban areas. Environ. Sci. Pollut. Res., 24: 18881-18895.

12. Krishnaveni, M.; Chandrasekar, R.; Amsavalli, L.; Madhaiyan, P. and Durairaj, S. 2013. Air pollution tolerance index of plants at Perumal Malai Hills, Salem, Tamil Nadu, India. Inter. J. Pharma Sci. Res., 20 (1): 234-239.

13. Kumari, J. and Deswal, S. 2017. Assessment of air pollution tolerance index of selected plants unveil to traffic roads of Noida, Uttar Pradesh. Inter. J. on Emerging Technologies, 8 (1): 179-184.

14. Moran, R. 1982. Formulae for determination of chlorophyllous pigments extracted with N, N-dimethylformamide. Plant Physiol., 69, 1376-1381.

15. Noor, M. J.; Sultana, S.; Fatima, S.; Ahmad, M.; Zafar, M. and Sarfraz, M. 2015. Estimation anticipated performance index and air pollution tolerance index and of vegetation around the marble industrial area of Potwar region: Bioindicators of plant pollution response. Health, 37 (3): 441-455.

16. Patel, D. and Kumar, J. I. N. 2018. An evaluation of air pollution tolerance index and anticipated performance index of some tree species considered for green belt 
development: A case study of Nandesari industrial area, Vadodara, Gujarat, India. Open J. Air Pollution, 7: 1-13.

17. Prasad, B.J. and Rao, D. N. 1982. Relative sensitivity of a leguminous and a cereal crop to sulphur dioxide pollution. Environ. Pollut., 29: 57-70.

18. Rahmawati, N.; Rosmayati, D. and Basyuni, M. 2014. Chlorophyll content of soybean as affected by foliar application of ascorbic acid and inoculation of arbuscular micorrhizal fungi in saline soil. Inter. J. Sci. Technol. Res., 3 (7): 127-131.

19. Sadasivam, S. and Manickam, A. 1996. Biochemical Methods: New Age International (P) Litd., Publishers, $2^{\text {nd }}$ ed., New Delhi, pp. 152-160.

20. Salaa, M.M. and Al-Kawaz, L. S. 2017. Assessment of air pollution using air polluation tolerance index (APTI) by two plant species (Concocarpus lancifolius and Dodonaea viscosa) in Babylon province. Mesopotemia Environ. J., 3 (2): 11-17.

21. SAS, Institute. 2009. SAS/STAT User`s Guides Statistics. Vers. 6.04, $4^{\text {th }}$ Ed., SAS. Institute Inc. Cary, N.C., USA.

22. Singh, S. K. and Rao, D. N. 1983. Evaluation of plants for their tolerance to air pollution. Symp. On Air Pollution Control. New Delhi, Proceedings. PP. 218-224.

23. Steel, R. G. D. and Torrie, J. H. 1980. Principles and procedures of statistics. McGrow Hill Book Co., Inc., New York, P: 377-400.

24. Tripathi, A.; Tiwari, P. B.; Mahima, A. and Singh, D. 2009. Assessment of air pollution tolerance index of some trees in Moradabad city. India. J. Environ. Biol., 30 (4): 545550.

25. Yan, D. and Hui, J. 2008. Variation in air pollution tolerance index of plants near a steel factory. Implications for landscape plant species selection for industrial areas. Wseas Transactions on Environ \& Develop., 1:24-30. 


\title{
تقييم قرة بعض أنواع نباتات الحديقة اليابانية على تحمل التلوث الهوائي (أ) مقارنة الأثواع المختلفة النامية في جزء محدد (مكان واحد) من الحديقة
}

\author{
فوزية غريب عبد النبي زنة 1، لبنى صلاح طه2 ، سبا محمد شاهين1 1 \\ 1. قسم بحوث الحدائق النباتية، معهُ بحوث البساتين، مركز البحوث الزراعية، الجيزة، مصر. \\ 2. قسم نباتات الزينة والأشجار الخشبية، العركز القومي للبحوث، الدقي، مصر.
}

لأن الأنواع المختلفة من النباتات نظهر عادة سلوكأ مختلفأ ضد النلوث الهو ائي في المواقع

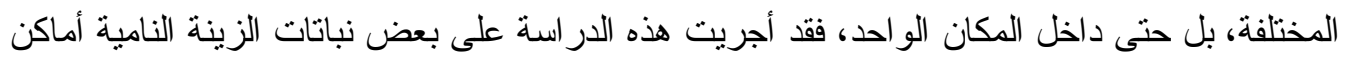
مختلفة من الحديقة اليابانية بمدينة حلوان الصناعية، القاهرة، مصر خلادل موسم الصيف 2017 لتحديد

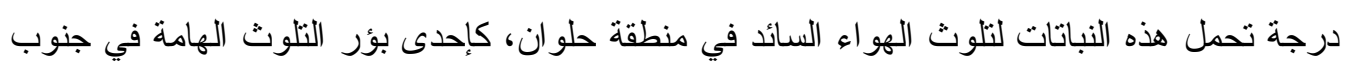

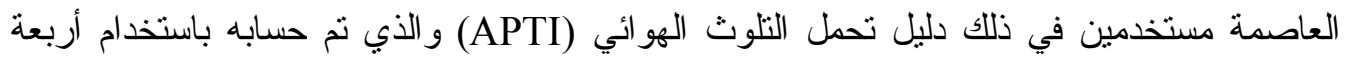
صفات طبيعيةكيموحيوية للأور اق، هي محتوى حمض الأسكوربيك، المحتوى النسبي للماء بالأوراق،

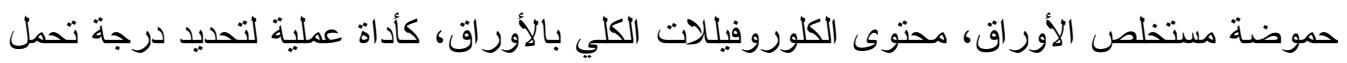

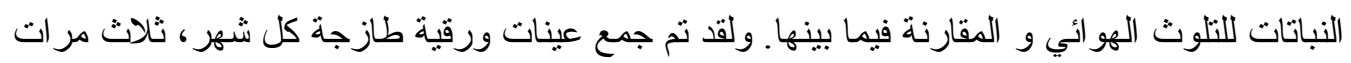

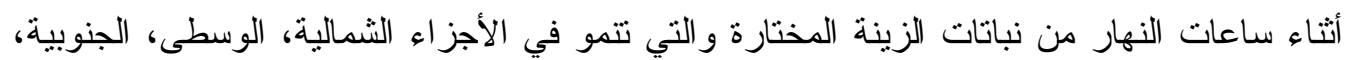

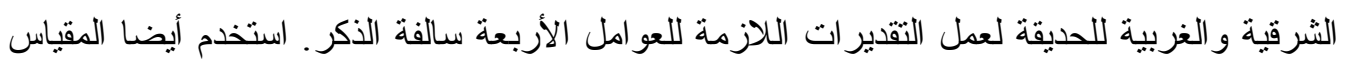
المدرج لدليل التحمل (APTI scale) لتحديد درجة حساسية أو تحمل كل نوع من الأنواع النباتية موضع الدر اسة.

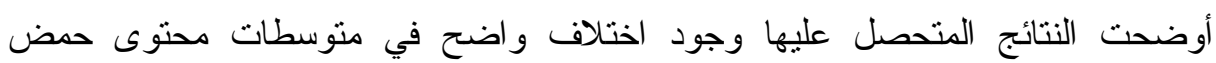

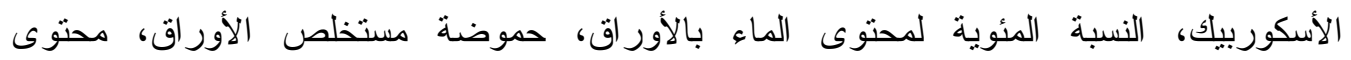

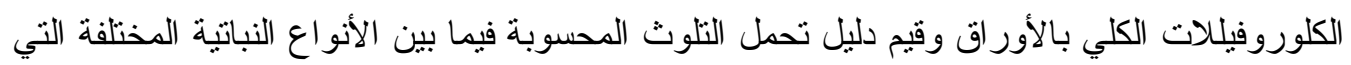

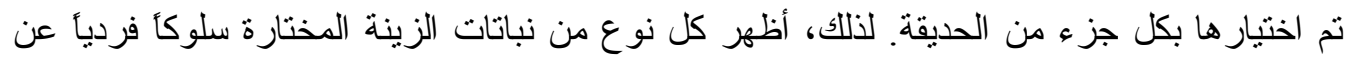

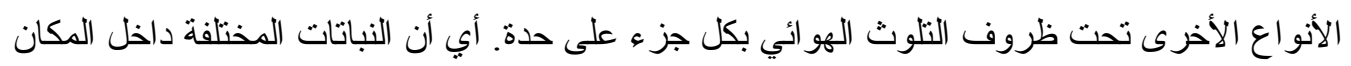

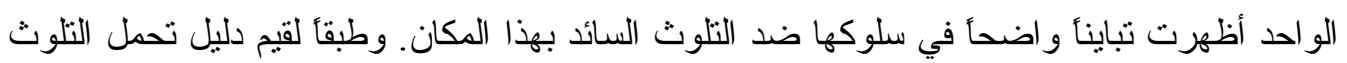
الهو ائي (APTI values) المحسوبة للأنو اع النباتية المختلفة في كل جزء في مستقل بالحديقة ودرجة التحمل المناظرة لها يمكن النصح بالأتي:

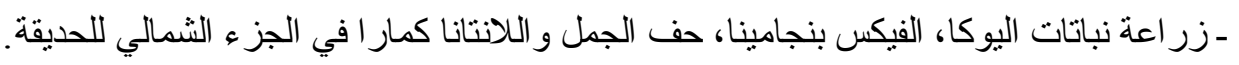
- زر اعة نباتات اليوكا، كاسيا نودوز ا، الخيار شمبر و الفيكس بنجامينا في الجز اءتهات الأوسط للحديقة.

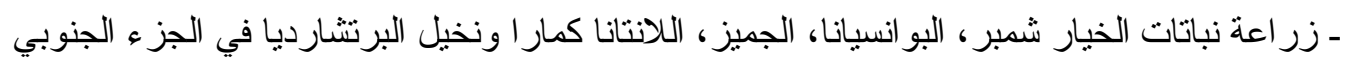

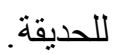
- زر اعة نباتات فيكس التين البنغالي، الكرونون، الدور انتا الخضر اء، و اللانتانا كمار ا في الجز ء الثرقي التئي

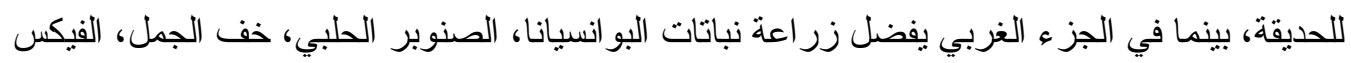

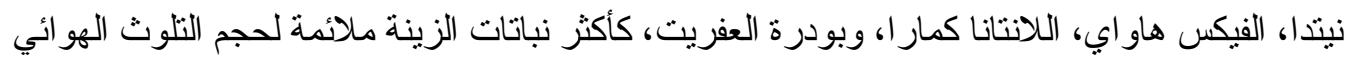



TO AIR POLLUTION

A. COMPARISON OF DIFFERENT SPECIES GROWN IN A SPECIFIC PART OF THE GARDEN 